Dept. of Virology, Faculty of Veterinary Medicine,

Banha University, 13736 Moshtoher, Egypt.

\title{
DETECTION AND ISOLATION OF ROTA (GROUP A) AND CORONA (GROUP 2) VIRUSES FROM NOMADIC CAMELS WITH SPECIAL REFERENCE TO PATHOLOGICAL ALTERATIONS
}

(With One Table and 6 Figures)

\section{By}

\section{S.S.A. SHARAWI and KH.Z. DOKHAN*}

Dept. of Pathology, Animal Reproduction Research Institute, Giza, Egypt.

(Received at 15/2/2010)

استكشاف وعزل فيروس الروتا (مجموعة أ) وفيروس الكورونا (مجموعة 2)

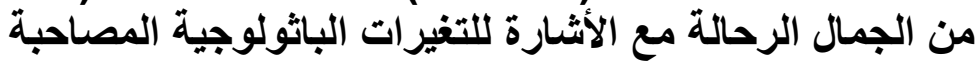

\section{سعد شعراوي على شعراوي ، خالد زكى دخان}

لدر اسة نو اجد فيروس الروتا (مجموعة أ) وفيروس الكورونا (مجموعة 2007) في قطعان جمال

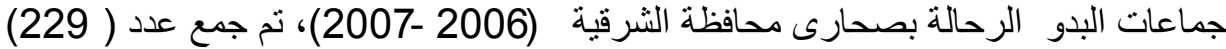
عينة براز من جمال شملت ( 130) عينة من جمال مصابة بالإسهال و وعالة عدد (

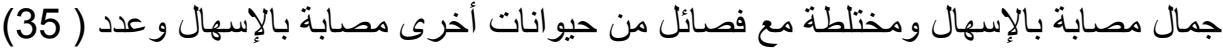

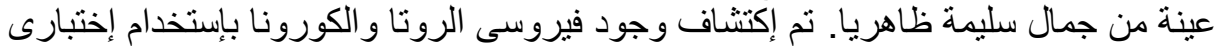

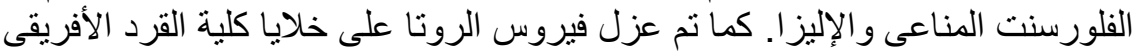

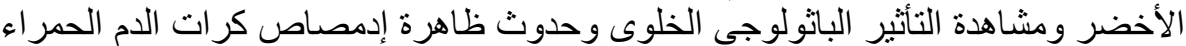

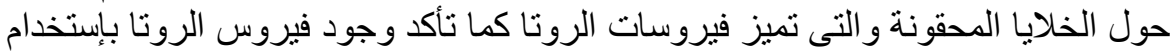

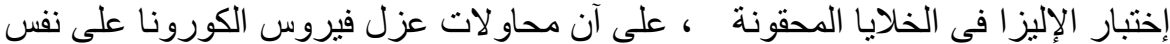

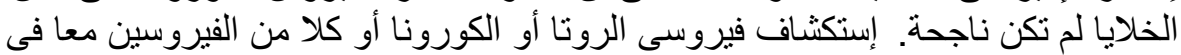

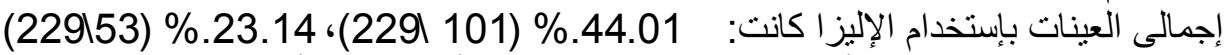

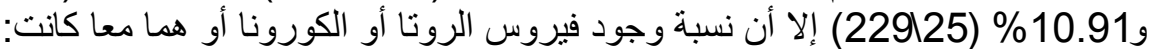

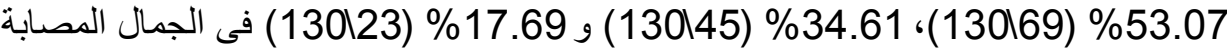

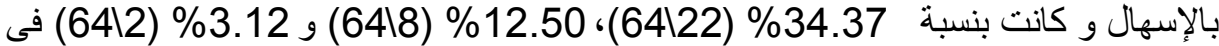
الجمال المصابة بالإسهال و المخالطة لحيو النات النات أخرى مصابة بالأسهال إلا أن النسبة كانت

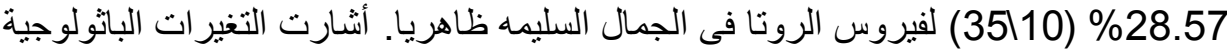

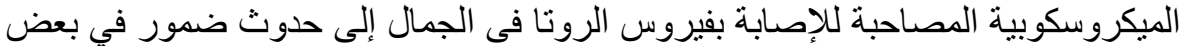

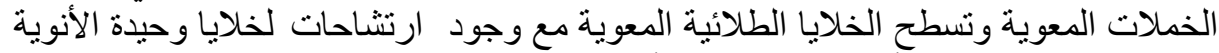

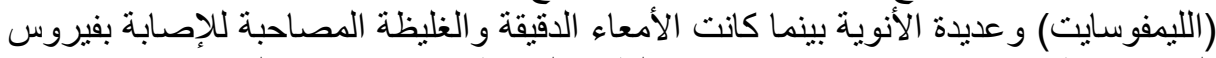
الكورونا يظهر بها بؤر عديدة من تقرحات الطبقة المخاطية ودرجات مختلفة من الاستسقاء لأناء 


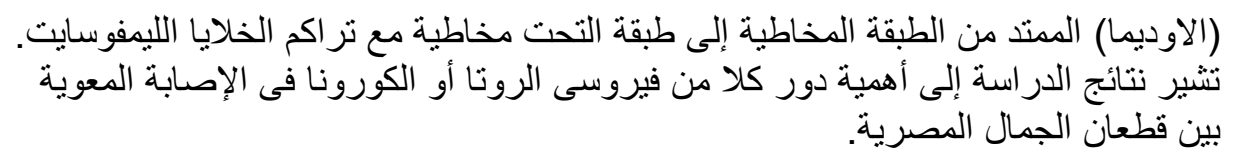

\section{SUMMARY}

To study the presence of rota (group A) and corona (group 2) viruses in camels, a total of 229 fecal samples were collected from diarrheic (130) as well as contact diarrheic( with other animal species) (64) and healthy camels (35) from different nomadic flocks from desert areas in Sharkia Governorate, Egypt during 2006- 2007. Group A rota virus infection was confirmed by direct fluorescent anti-body technique (FAT), virus isolation and detection of rota virus antigen by immune-captured enzyme linked immune sorbent assay (Ic-ELISA) in feces and harvested inoculated cell, as well as demonstration of cytopathic effect (CPE) and haemadsorbtion criteria of rota virus on Vero cell. Corona virus antigen was detected by FAT, Ic-ELISA but all attempts for corona virus isolation were entirely failed. Specific rota virus or corona virus antigens or both; were detected by Ic-ELISA; in $44.01 \%$ (101/229), $23.14 \%$ $(53 / 229)$ and $10.91 \%(25 / 229)$ of the total examined fecal specimens, respectively, of which $53.07 \%$ (69/ 130), 34.61\% (45/130) and $17.69 \%$ $(23 / 130)$ were from diarrheic, $34.37 \%$ (22/64), $12.50 \%(8 / 64)$ and $3.12 \%$ (2/64) from contact animals for rota, corona or both virus antigens, respectively and $28.57 \%$ (10/35), for rota virus only from healthy camels. The results show that the rota virus is widespread, mainly among camels from 6 to 12-months old, while corona virus alone or mixed with rota virus was 1 to 2 years old. The histopathological changes in small intestine associated with rota virus infection were observed in villus atrophy and flattening of the epithelial cells. The small and large intestines infected by corona virus had multifocal mucosal ulceration and various degrees of mucosal to submucosal edema with moderate accumulation of lymphocytes. These findings emphasis the significant role of rota virus and corona virus or both in the enteric infection of camels in Egypt.

Key words: Camel, corona virus, rota virus, pathology.

\section{INTRODUCTION}


Rota and corona viruses encountered as an important potential pathogens of different mammals including camels causing serious enteritis, pneumonia, dehydration and some death particularly neonated cases (Berrada et al., 1999, Wünschmann et al., 2002, Cebra et al., 2003 and Tibary et al., 2006) (Orr 1984, Alfieri et al., 2006; Oliveira Filho et al., 2007). Rota viruses are taxonomically grouped in the Reoviridae family characterized by a double-stranded RNA genome that consists of 11 gene segments enclosed in a double-shelled protein capsid (Derbyshire and Woode, 1978 and Kalica et al., 1978). Rota viruses are divided into 6 distinct groups designated A through $\mathrm{F}$, with evidence accumulating to support the possible inclusion of one more group. Group A rota viruses (GARV) are most often associated with diarrhea among farm animals and humans (Bridger, 1987). Corona virus has been reported in sheep, goats and llamas (Evermann and Benfield, 2001 and Cebra et al., 2003), though it is more commonly identified as a problem in cattle (Tzipori, 1981 and Decaro et al., 2008) causing infections of mucosal surfaces, of the respiratory and digestive systems (Evermann and Benfield, 2001 and Lai et al., 2006). Corona viruses are large, enveloped single-stranded with positive polarity RNA viruses in the family Coronaviridae order Nidovirales (Vries et al., 1997), have three distinct antigenic groups based on their serologic characterization (Claude et al., 2005). Corona viruses isolated from mammals and humans are categorized in Groups 1 and 2 (Lai et al., 2006). Bovine corona virus $(\mathrm{BCoV})$ and alpaca corona virus $(\mathrm{ApCoV})$ are both members of group 2 (Davis et al., 2000 and Claude et al., 2005). Detection of rota or corona viruses in fecal samples was confirmed with FAT, ELISA, RT-PCR, or nested PCR (Park et al., 2006). However, there are inadequate data on the incidence, as well as the isolation and histopathology of rota virus and corona virus infections, in camels located in Egypt. The objective of the present work was planned for detection, isolation and estimation the rate of rota and corona viruses infection in nomadic camels at Sharkia Governorate.

\section{MATERIALS and METHODS}

\section{Sample collection and preparation:}

During 2006 - 2007, a total of 229 fecal samples were randomly collected from diarrheic as well as contact diarrheic (with other animal species) and healthy camels from different nomadic Bedouin camel 
flocks from desert areas in Sharkia Governorate, Egypt. Fecal samples were collected from the rectum following digital stimulation. A suspension of fecal material was prepared in a 1:10 proportion $(\mathrm{p} / \mathrm{v})$ in phosphate-buffered saline (PBS 0.01 M pH 7.2), centrifuged at 7000 $\mathrm{rpm} / \mathrm{m}$ under refrigeration for 30 minutes. Supernatant was filtered through a $0.45 \mu \mathrm{m}$ (Millex® USA) system. One portion included various regions of small and large intestines of each diarrheic slaughtered animal were fixed in neutral buffered formalin, for routine histopathological examination.

\section{Direct fluorescent anti-body technique (FAT):}

The lumenal surface of intestinal segments was cellularly scraped, transferred to an eppendorf centrifuge tube, and $1 \mathrm{ml}$ PBS was added. The sample was vortexed and clarified by centrifugation at 5000 $\mathrm{rpm} / \mathrm{m}$ for $5 \mathrm{~min}$. The supernatant was decant and sediment cells were resuspended in $1 \mathrm{ml}$ PBS with vortex, then pipetted $(50 \mu \mathrm{l})$ over a depressed microscope slide, dried at $37{ }^{\circ} \mathrm{C}$ then fixed at aquas acetone ethanol $(1: 1)$ over night at $4{ }^{0} \mathrm{C}$, then washed triple with PBS. Hyper immune serum fluorescein-labelled [fluorescein isothiocyanated] for bovine rota or bovine corona viruses (VHRD, Pullman, USA) was added (50 $\mu \mathrm{l} /$ slide). All examined slides were incubated at $37{ }^{\circ} \mathrm{C}$ for one h., followed by triple washing with PBS containing $0.1 \%$ bovine albumin (BD-BBL, Ireland), then mounted in glycerol saline and examined under fluorescent microscope (Burleson et al., 1997).

\section{Immune captured enzyme linked immune sorbent assay (Ic-ELISA):}

All collected fecal samples were submitted to commercial Ic-ELISA [Bio-x Diagnostic, Belgium], as well as all inoculated cells (positive or negative CPE) to confirm and identify the obtained viral isolate. The kits can only detect the presence of group A bovine rota virus (BRoV) and group $2 \mathrm{BCoV}$ antigens.

\section{Cell culture, viral isolation and titeration:}

Of the positive in Ic-ELISA, some of the tested samples $(5+\mathrm{ve}$ rota $\& 5+$ ve corona) were chosen and attempts for viruses isolation in cell culture was carried out. Monolayers of Vero cells adapted to growth in Minimum Essential Medium Eagle (MEM - Cultilab®) with 10\% of bovine fetal serum $\left(\mathrm{Cultilab}{ }^{\circledR}\right)$ were used. One $\mathrm{ml}$ of the diluted $(1: 10)$ filtered fecal suspension was inoculated, in triplicate, in monolayers Vero cell with 48 hours of growth in plastic bottles $\left(25 \mathrm{~cm}^{2}\right)$. Previous 
growth medium was discarded and monolayers were washed twice in MEM before the inoculation. After One hour of adsorption under low stirring at $37^{\circ} \mathrm{C}$, the inoculum was discarded. Eight $\mathrm{ml}$ of MEM were added. Bottles were incubated at $37^{\circ} \mathrm{C}$ and cytopathic effect (CPE) was observed until 96 hours after inoculation. Monolayers were then frozen for the next passages, which were performed with $1 \mathrm{ml}$ of the respective previous passage. As the negative control, inoculum with PBS was used; isolates were considered positive when the cytopathic effect was observed till the $3^{\text {rd }}$ passage to exclude non specific CPE. Random positive harvested inoculated plastic bottles (CPE, haemadsorbtion and Ic-ELISA +ve) were polled for estimation the infectivity titration of the viral isolate to obtained $\mathrm{TCID}_{50} / \mathrm{ml}$ according to Reed and Muench, (1938).

\section{Haemadsorbtion assay:}

The test was performed according to Vogel and Shelokov (1957). After 2 or 3 days of incubation; whether or not suspected CPE has occurred; the tissue culture media are removed and cells were washed twice with PBS and then incubated for one h. with a $0.4 \%$ suspension of guinea pig erythrocytes (RBCs). The bottles are incubated for $1 \mathrm{~h}$. at $4^{\circ} \mathrm{C}$, $22^{\circ} \mathrm{C}$ or at $37^{\circ} \mathrm{C}$, rinsed briefly with PBS to resuspend the settled RBCs, and then examined under low or high magnification. Positive haemadsorption is detected by firm adhesion of the RBCs which must not float across the monolayer when the bottle is gently agitated. Individual infected cells as well as the ratio of infection can be demonstrated.

\section{Histopathological examination:}

Representative tissue specimens were fixed in neutral buffered formalin, embedded in paraffin, sectioned at $4 \mu \mathrm{m}$ and stained with hematoxylin and eosin (Bancroft and Stevens, 1990).

\section{RESULTS}

Examination of intestinal sediment cells of totally 30 samples by FAT revealed 3, 7 and 3 positive samples for rota, corona and both virus antigens, respectively (Fig. 1).

Specific rota virus or corona virus antigens or both; were detected (Table 1) by Ic-ELISA, in 44.01\% (101/229), 23.14\% (53/229) and $10.91 \%(25 / 229)$ of the total examined fecal specimens, respectively, of which $53.07 \%$ (69/ 130), 34.61\% (45/130) and 17.69\% (23/130) were 
from diarrheic, $34.37 \%(22 / 64), 12.50 \%(8 / 64)$ and $3.12 \%(2 / 64)$ from contact and $28.57 \%(10 / 35)$, from healthy camels for rota, corona or both virus antigens, respectively. The results show that the rota virus; $54.83 \%$ (34/62); is widespread, mainly among camel from 6 to 12 months-old, while corona virus alone or mixed with rota virus was $38.23 \%, 14.70 \%(13 / 34,5 / 34)$, respectively at 1 to 2 years old.

Among fecal samples studied for the presence of rota or corona virus by Ic-ELISA, 10 positive samples were tested to isolate the viruses in Vero cells, 5 samples $(5 / 5=100 \%)$ for rota virus presented rounding, granulation, processing and syncytial cytopathic effect until the fifth passage with haemadsorbtion for added RBCs (Fig. 2). The CPE in Bottles indicated that the isolates were confirmed as positive for rota virus by Ic-ELISA. When titration of the rota virus isolate was performed, a titer equal to $10^{5.4} \mathrm{TCID}_{50} / \mathrm{ml}$ was obtained. All trails for corona virus isolation have been failed.

The histopathological examination of rota virus infected intestines revealed that the virus specially attacks the epithelium of small intestine. The epithelial cells are lost from the tips of villi. These desquamated cells are replaced by cuboidal, then flattened squamous epithelial cells resulting in villus atrophy. Some villi remained denuded and their stroma became internally infiltrated with mononuclear inflammatory cells and moderate neutrophilic infiltration in the lamina propria (Fig.3). The small and large intestines infected by corona virus had multifocal mucosal ulceration and various degrees of mucosal to submucosal edema with moderate accumulation of lymphocytes and plasma cells (Fig.4). Severe congestion of blood capillaries and wide dilatation of the lymphatics in some villi were found (Fig.5). Mild hypercellularity was observed in the mucosal lamina propria of most sections of colon and cecum. In mixed infections of rota and corona viruses of intestine destruction and necrosis of the intestinal villi and mononuclear inflammatory cell infiltration were found (Fig. 6). 
Table 1: Detection of rota (group A) and corona (group 2) viruses antigens in camel fecal samples by ELISA:

\begin{tabular}{|c|c|c|c|c|c|c|c|c|c|c|c|c|c|c|c|}
\hline \multirow[t]{2}{*}{ Age } & \multirow{2}{*}{$\begin{array}{c}\text { No. of } \\
\text { Samples } \\
\text { tested }\end{array}$} & \multirow[t]{2}{*}{ Signs } & \multirow{2}{*}{$\begin{array}{c}\text { No. } \\
\text { Samples }\end{array}$} & \multicolumn{4}{|c|}{ ROTA } & \multicolumn{4}{|c|}{ CORONA } & \multicolumn{4}{|c|}{ ROTA \& CORONA } \\
\hline & & & & $+\mathrm{V}$ & $\begin{array}{c}\% \text { of } \\
\text { positive } \\
\text { samples }\end{array}$ & \begin{tabular}{|l|} 
Total \\
$+\mathrm{V}$ \\
samples
\end{tabular} & $\begin{array}{l}\% \text { of } \\
\text { positive } \\
\text { samples }\end{array}$ & $+\mathrm{V}$ & $\begin{array}{l}\% \text { of } \\
\text { positive } \\
\text { samples }\end{array}$ & $\begin{array}{c}\text { Total } \\
+\mathrm{V} \\
\text { samples }\end{array}$ & $\begin{array}{l}\text { \%of } \\
\text { positive } \\
\text { samples }\end{array}$ & $+\mathrm{V}$ & $\begin{array}{c}\% \text { of } \\
\text { positive } \\
\text { samples }\end{array}$ & $\begin{array}{c}\text { Total } \\
+\mathrm{V} \\
\text { samples }\end{array}$ & \begin{tabular}{|c|}
$\%$ of \\
positive \\
samples
\end{tabular} \\
\hline \multirow{3}{*}{$\begin{array}{c}>3 \\
\text { months }\end{array}$} & \multirow[t]{3}{*}{74} & $\mathrm{H}^{1}$ & 11 & 2 & $18.18 \%$ & \multirow[t]{3}{*}{$32 / 74$} & \multirow[t]{3}{*}{$43.24 \%$} & 0 & $0.00 \%$ & \multirow[t]{3}{*}{$20 / 74$} & \multirow[t]{3}{*}{$27.02 \%$} & 0 & $0.00 \%$ & \multirow[t]{3}{*}{$11 / 74$} & \multirow{3}{*}{$\begin{array}{c}14.86 \\
\%\end{array}$} \\
\hline & & $\mathrm{C}^{2}$ & 18 & 7 & $38.88 \%$ & & & 3 & $16.66 \%$ & & & 1 & $5.55 \%$ & & \\
\hline & & $\mathrm{D}^{3}$ & 45 & 23 & $51.11 \%$ & & & 17 & $37.77 \%$ & & & 10 & $22.22 \%$ & & \\
\hline \multirow{3}{*}{$\begin{array}{c}\text { 6-12 } \\
\text { months }\end{array}$} & \multirow[t]{3}{*}{62} & $\mathrm{H}$ & 9 & 4 & $44.44 \%$ & \multirow[t]{3}{*}{$34 / 62$} & \multirow[t]{3}{*}{$54.83 \%$} & 0 & $0.00 \%$ & \multirow[t]{3}{*}{$13 / 62$} & \multirow[t]{3}{*}{$20.96 \%$} & 0 & $0.00 \%$ & \multirow[t]{3}{*}{$8 / 62$} & \multirow{3}{*}{$\begin{array}{c}12.90 \\
\%\end{array}$} \\
\hline & & $\mathrm{C}$ & 12 & 3 & $25.00 \%$ & & & 1 & $8.33 \%$ & & & 0 & $0.00 \%$ & & \\
\hline & & $\mathrm{D}$ & 41 & 27 & $65.85 \%$ & & & 12 & $29.26 \%$ & & & 8 & $19.51 \%$ & & \\
\hline \multirow{3}{*}{$\begin{array}{c}1-2 \\
\text { year }\end{array}$} & \multirow[t]{3}{*}{34} & $\mathrm{H}$ & 6 & 2 & $33.33 \%$ & \multirow[t]{3}{*}{$12 / 34$} & \multirow[t]{3}{*}{$35.29 \%$} & 0 & $0.00 \%$ & \multirow[t]{3}{*}{$13 / 34$} & \multirow[t]{3}{*}{$38.23 \%$} & 0 & $0.00 \%$ & \multirow[t]{3}{*}{$5 / 34$} & \multirow{3}{*}{$\begin{array}{c}14.70 \\
\%\end{array}$} \\
\hline & & $\mathrm{C}$ & 11 & 4 & $36.36 \%$ & & & 2 & $18.18 \%$ & & & 1 & $9.09 \%$ & & \\
\hline & & $\mathrm{D}$ & 17 & 6 & $35.29 \%$ & & & 11 & $64.70 \%$ & & & 4 & $23.52 \%$ & & \\
\hline \multirow{3}{*}{$\begin{array}{c}<2 \\
\text { year }\end{array}$} & 59 & $\mathrm{H}$ & 9 & 2 & $22.22 \%$ & $23 / 59$ & $38.98 \%$ & 0 & $0.00 \%$ & \begin{tabular}{|l|}
$7 / 59$ \\
\end{tabular} & $11.86 \%$ & 0 & $0.00 \%$ & $1 / 59$ & $1.69 \%$ \\
\hline & & $\mathrm{C}$ & 23 & 8 & $34.78 \%$ & & & 2 & $8.69 \%$ & & & 0 & $0.00 \%$ & & \\
\hline & & $\mathrm{D}$ & 27 & 13 & $48.14 \%$ & & & 5 & $18.51 \%$ & & & 1 & $3.70 \%$ & & \\
\hline No. c & each & $\mathrm{H}$ & 35 & 10 & $(10$ & /35) 28.57 & & 0 & & $0.00 \%$ & & 0 & & $0.00 \%$ & \\
\hline clinical & y samples & $\mathrm{C}$ & 64 & 22 & $(22$ & 34.37 & & 8 & & $4 \%) 12.50$ & & 2 & & 64) $3.12 \%$ & \\
\hline & & $\mathrm{D}$ & 130 & 69 & $(69)$ & 130 53.0 & $97 \%$ & 45 & & 130) 34.61 & & 23 & $(23)$ & $130 \lcm{17.69}$ & \\
\hline Total ex & amined sar & nples & 229 & 101 & $(101$ & /229) 44.1 & $10 \%$ & 53 & & 23.1 & & 25 & $(25)$ & 229) 10.91 & \\
\hline
\end{tabular}

1: Healthy; 2: Contact diarrheic and 3: diarrheic. 


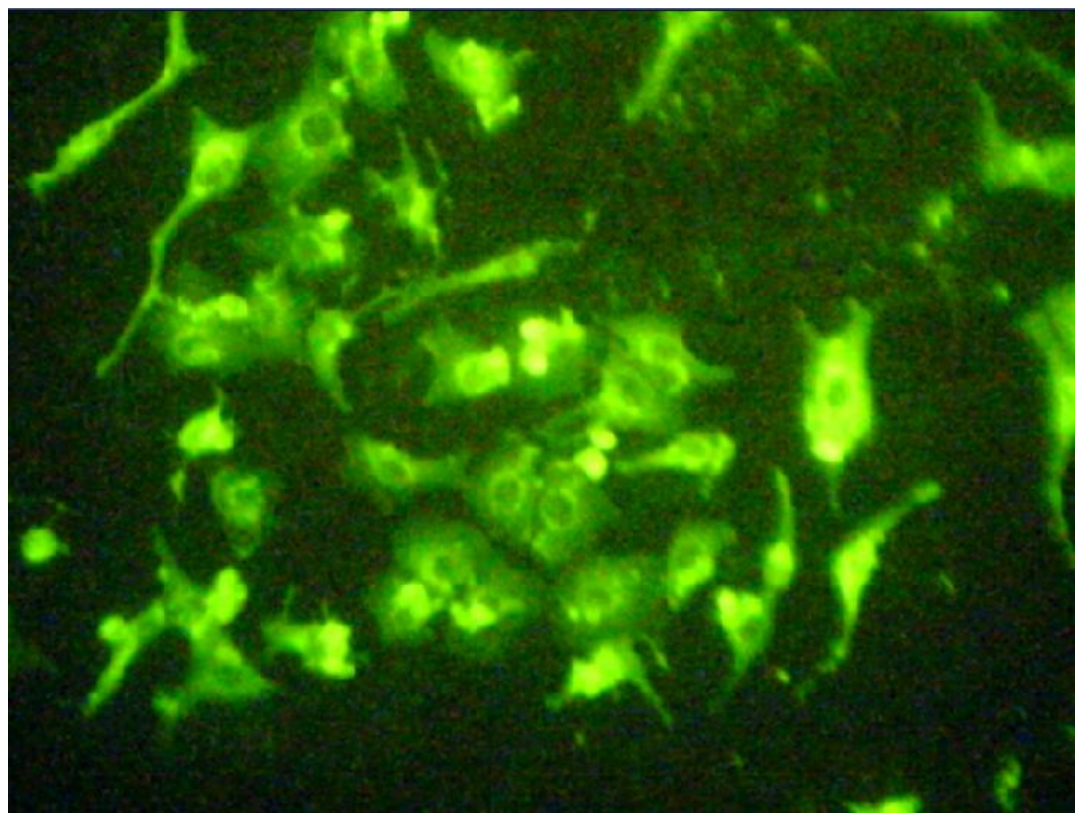

Fig. 1: FAT, Intracytoplasmic perinuclear fluorescence in the positive enterocyte.

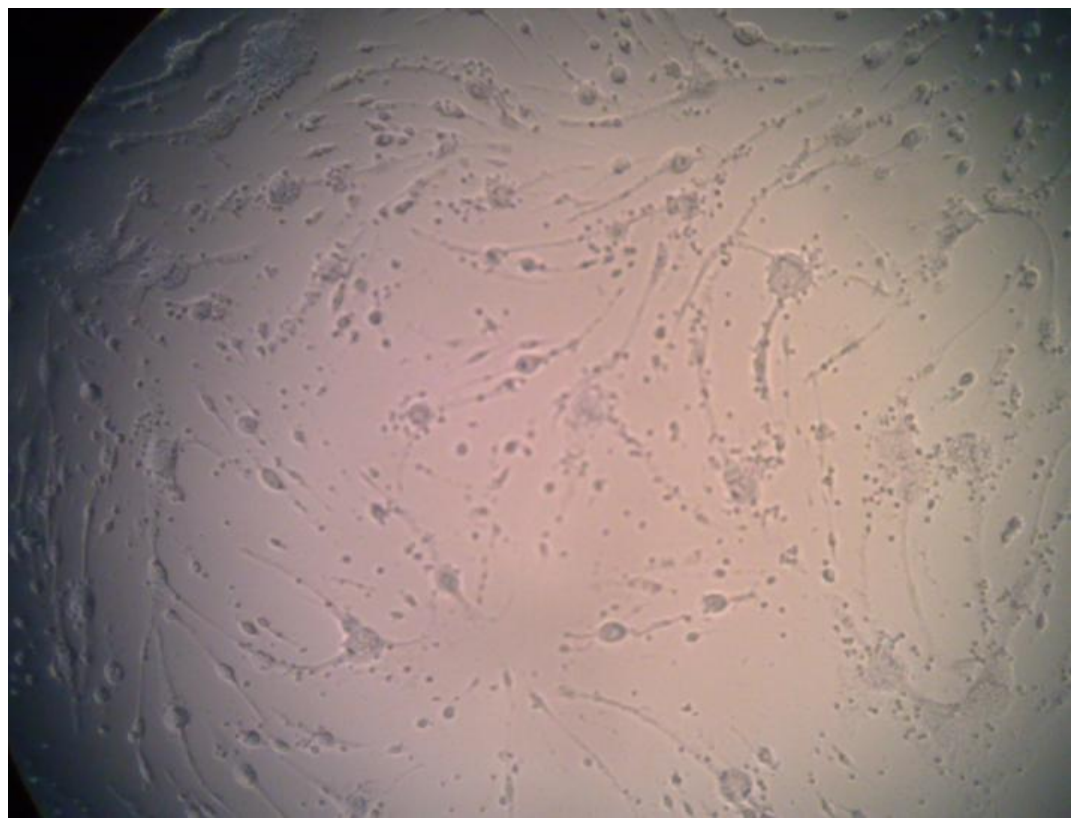

Fig. 2: Camel rota virus infected Vero cells reveals positive haemadsorption. 


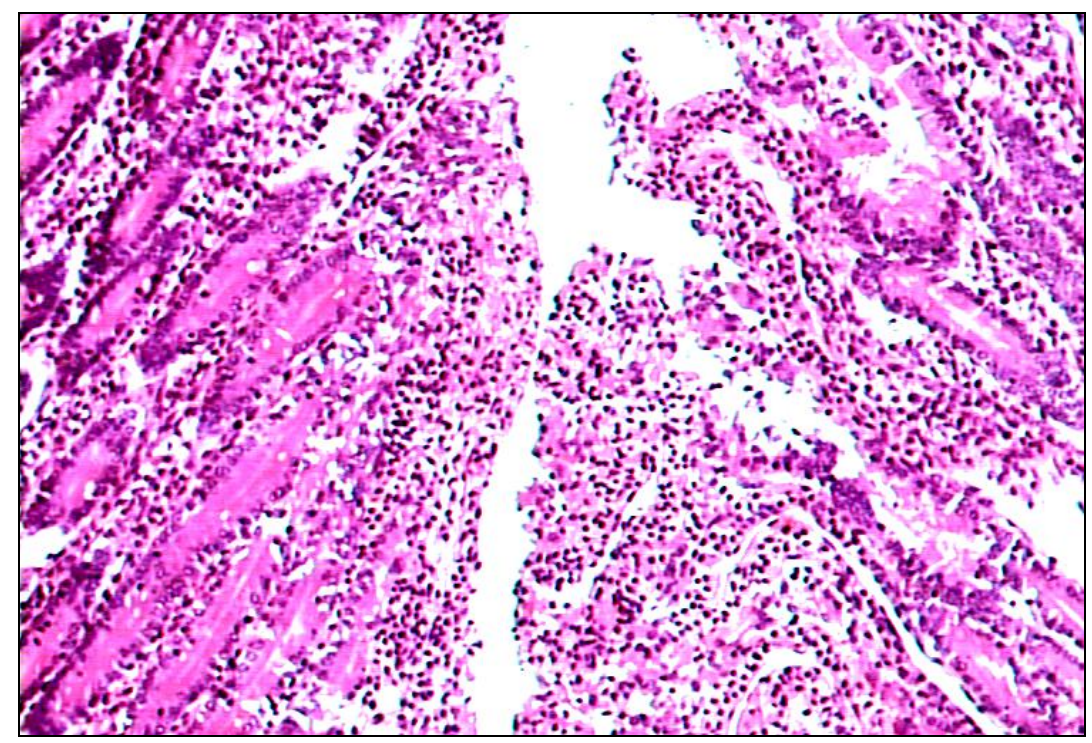

Fig. 3: Duodenum of camel calf infected with Rota virus showing intense infiltration of mononuclear inflammatory cells and moderate neutrophilic infiltration in the lamina propria (H\&E; X100).

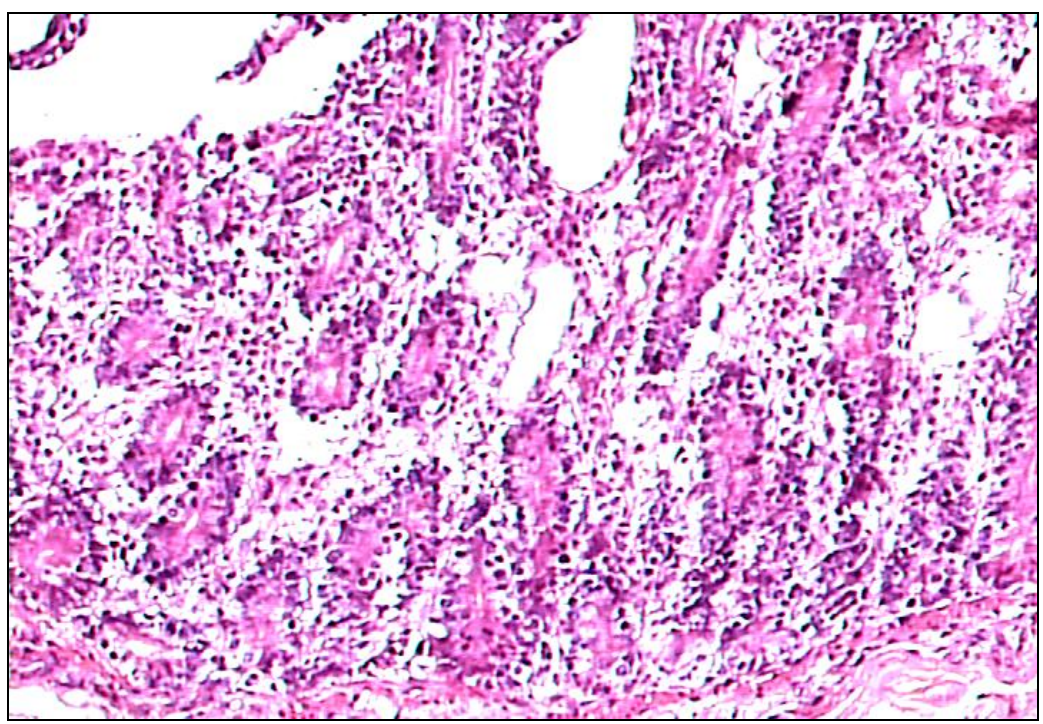

Fig. 4: Jejunum of camel calf infected with Corona virus showing mononuclear inflammatory cells and moderate edema in the lamina propria (H\&E; X100). 


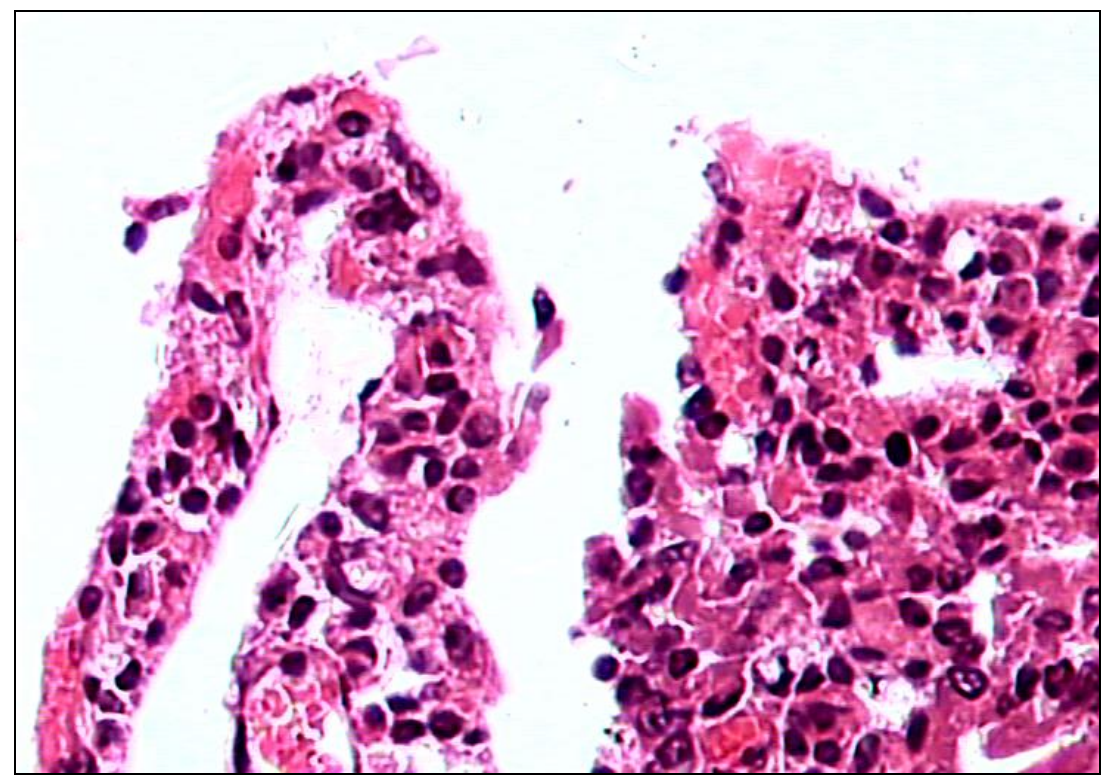

Fig. 5: Ileum of camel calf infected with Corona virus showing severe congestion of the blood capillaries and wide dilatation of the lymphatic in some villi (H\&E; X400).

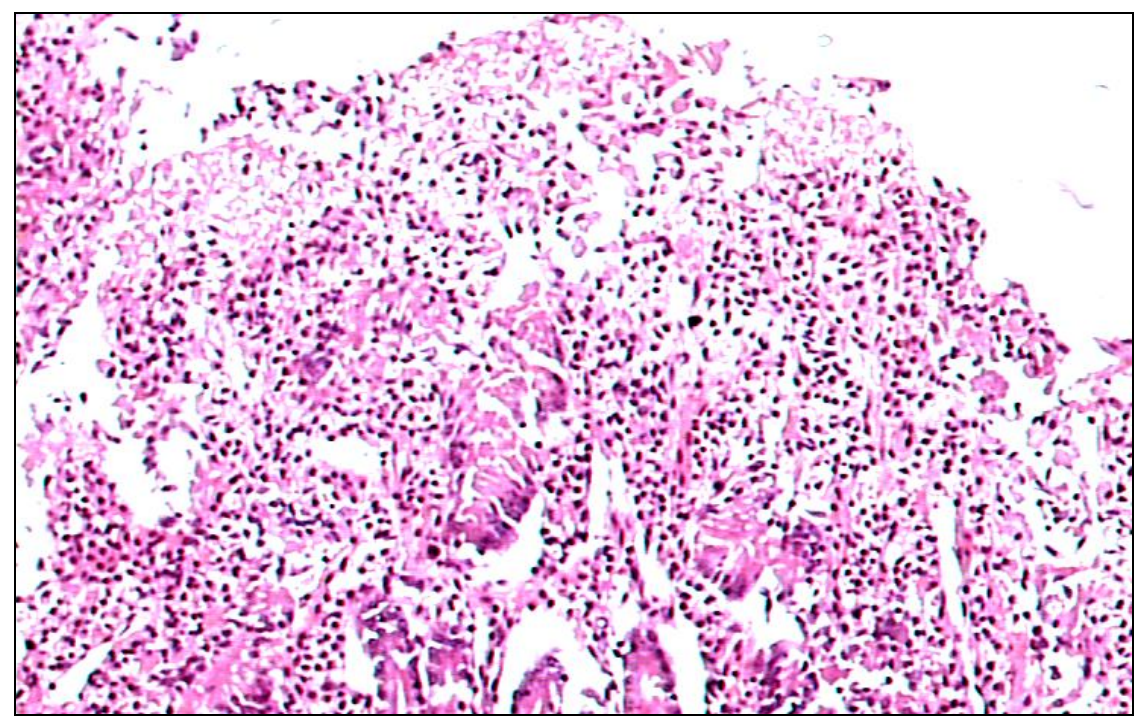

Fig. 6: Ileum of camel calf infected with Rota virus and Corona virus showing destruction and necrosis of the intestinal villi with mononuclear inflammatory cell infiltration (H\&E; X100). 


\section{DISCUSSION}

In this study, FAT has been used to stain intestinal cells from infected camels, where positive rota and corona virus antigens were detected, although, the staining results (positive/negative) tend to lack detail on intensity/distribution of staining. Although the immunofluorescence (IF) has been used to stain cells or cell debris excreted in stools from viral infected calves; the problem of non-specific fluorescence has prevented its widespread use on stools, but this can be overcome if the virus antigen is first separated by immune precipitation prior to staining (WHO, 1980). However, this method is laborious and time-consuming when done on a large scale. A simpler method is needed to make detection of rota or corona viruses in camel feaces more acceptable. The ELISA is reproducible, rapid and quantitative method for the detection of corona virus, rota virus and reovirus antigens particularly suited for the large-scale testing of fecal samples, the prevalence of rota and corona virus antigens was higher by ELISA than by EM. (Yolken et al., 1977 and Dea and Tijssen, 1988).

In this work, an indirect antigen capture ELISA employing monoclonal antibodies (MAbs) to $\mathrm{BRoV}$ and $\mathrm{BCoV}$ as the capture antibodies was used to detect $\mathrm{BRoV}$ and $\mathrm{BCoV}$ in the camel fecal suspensions because of their relative simplicity and speed. The results obtained revealed that rota virus or corona virus antigens or both; were detected, in $44.01 \%, 23.14 \%$ and $10.91 \%$ of the total examined fecal specimens respectively. These results like to some extent the frequency of bovine GARV (11 to 19.4\%), BCoV (14 to 39\%) (Alfieri et al., 2006; Takiuchi et al., 2006 and Oliveira Filho et al., 2007) and the bovine GARV and $\mathrm{BCoV}$ co-infection in $(15.9 \%)$ recorded in cattle herds (Fernandes et al., 2009).

Our positive Ic-ELISA revealed $53.07 \%, 34.61 \%$ and $17.69 \%$ were from diarrheic, $34.37 \%, 12.55 \%$ and $3.12 \%$ from contact for rota, corona or both virus antigens respectively and $28.57 \%$, from healthy camels for rota virus only. A high frequency of viruses associated were with that diarrheic camels, as previously described for prevalence of rota virus (26.98\%) and Corona virus (3.17\%) infection in diarrheic calves in Iran (Mayameei et al., 2009). In addition, rota virus infection were the most common causes of diarrhea in camel calves from 6 to 12-monthsold (Wernery, 1999 and Wernery and Kaaden, 2002), while corona virus alone or mixed with rota virus was at 1 to 2 years old. Anyhow; bovine corona virus was the principal virus particle present in samples of winter 
dysenteric adult cattle (Saif et al., 1988), whereas chronically infected adult animals are often a source of the corona virus infection (Clark, 1993).

Interestingly, in the current study; healthy camels had a score for rota virus antigen detection. The exact reason for this finding is unknown. However Since the initial description of the clinical signs of rota virus-induced diarrhea in calves, much has been learned about the epidemiology of rota virus infection (Mebus et al., 1969). Rota viruses can be found in fecal samples from normal healthy animal or in animals exhibiting clinical disease of varied severity (Dea, et al., 1985). The source of the rota or corona viral infection is uncertain in the diarrheic or healthy camels present case. The fact that other contact animals species in the herd had a history of diarrhea supports the concept that there were either acquired or exchange of rota or corona viral infection among camels and the other animal species. Additionally, the possible interspecies corona virus infection may have implication for the cohusbandry of individuals of the family Camelidae with individuals of other families such as Bovidae, Cervidae, and Equidae (Wünschmann et al., 2002). The findings of the present study are supported by a recent report in which a corona virus antigenically related to $\mathrm{BCoV}$ was identified in a wild ruminants (Tsunemitsu et al., 1995) elk calves (Majhdi et al., 1997), foal (Davis et al., 2000 and Elizabeth et al., 2000) llamas and alpacas (Cebra et al., 2003), While the group A rota virus was identified to be a common intestinal infection in animals and has been demonstrated as a cause of diarrhea in mice, calves, piglets, foals, young rabbits, deer, pronghorn antelope, chickens, turkeys, goats, kittens, a chimpanzee, and a gorilla. There is also evidence that it can infect other animals, as shown by virus isolation studies in monkeys and dogs (WHO, 1980 and Ijaz et al., 1989).

Although most field strains of BCoV grow poorly in cell culture and fail to produce CPE until after blind passage, primary calf kidney (PCK) and Vero cells have permitted primary isolation of virus (Linda et al., 1988) while; BRV were isolated from fecal specimens in Vero cells (Sato et al., 1997). In the present study, isolation of camel corona virus in Vero cells were completely failed where no CPE or Ic- ELISA viral detection; until after 5 blind passages; were obtained, whereas camel group A rota virus was isolated in Vero cells and identified by IcELISA.where CPE were manifested on days 3-5 on the $2^{\text {nd }}-5^{\text {th }}$ passages as rounding, elongation, and granulation of cells. This characteristic CPE goes hand in hand with the growth characteristics in MDBK cells of a 
calf rotavirus isolated in Northern Ireland (McNulty et al., 1977) and those recorded in MA104 cells during detection and isolation of group A rota virus from camel calves in Sudan which were identified by ELISA and EM (Ali et al., 2004). This finding may attributed to the presence of proteolytic enzymes. The ability of pancreatic proteolytic enzymes to enhance rota virus infectivity in both permissive and semipermissive cell lines was recorded, the degree of enhancement observed was dependent upon the initial multiplicity of infection and the host cell line employed, Vero cells showed that trypsin treatment allowed multiple rounds of rota virus replication to occur in these cells (Graham and Estes, 1980).

In present work, camel rota virus infected Vero cells were positive for haemadsorption assay. This finding strongly pointed to the relation of this isolated virus to $\mathrm{BRoV}$ as among the rota viruses for which the presence of a haemagglutinin has been demonstrated are rota calf diarrhoea virus (Spence et al., 1976 \& 1978 and Inaba et al., 1977).

In titration of the camel rota virus isolate, a greatest titer observed was equal to $10^{5.4} \mathrm{TCID}_{50} / \mathrm{ml}$, thus confirm the hypothesis of high viral concentration, what may contribute for more knowledge of CRV antigenic properties and consequently; seroneutralization assay in microplates may be used in the future to detect and titerate the camel rota virus antibodies in camel flocks.

The histopathological changes associated with rota virus infection were observed in villous atrophy and flattening of the epithelial cells. These changes were consistent with the lesion previously described in natural or experimental rota virus infections in bovine calve, piglets and mice (Mebus et al., 1971, Carpio et al., 1981, and Jos et al., 2003). In many domestic animals, the features of the infection, the intestinal involvement and the pathogenesis are similar to bovines, even though considerable serotype differences exist among animal rota viruses of different geno-groups (Wani et al., 2004 and Fukai et al., 2006). After entry through oral route, rota viruses have been found to replicate in the mature villous epithelial cells (enterocytes). For their efficient colonization and infectivity, viruses need their outer capsid to be cleaved and removed, which is facilitated by intestinal proteases like chymotrypsin (Ramig, 2004 and Desselberger et al., 2005). The small and large intestine infected by corona virus had multifocal mucosal ulceration and various degrees of mucosal to submucosal edema with moderate accumulation of lymphocytes. This is in agreement with previously record in bovine calves (Mebus et al., 1973, Mebus et al., 1975 and Sharpee et al., 1976). On the other hand, Wünschmann et al. 
(2002) recorded that pathological changes were probably marked in the colon and cecum than the parts of small intestine in camel calves and mixed nonhemolytic coliforms and nonhemolytic Streptococcus sp. were cultured from colon. In addition, the corona virus infection may have predisposed the animal to the putative fatal clostridial infection.

In conclusion; the results of the present study refer to the significant role of rota virus and corona virus or both in the enteric infection of camels in Egypt. In addition, the study refers the antigenic similarities between bovine and camel rota and corona viruses and suggest that camel may be a source for rota or corona viruses that infect domestic ruminants or vice versa. However, Molecular studies should warranted to clear-up the detailed pathogenesis and strains variance.

\section{REFERENCES}

Alfieri, A.A.; Parazzi, M.E.; Takiuchi, E.; Médici, K.C. and Alfieri, A.F. (2006): Frequency of group A rota virus in diarrheic calves in Brazilian cattle herds, 1998-2002. Trop. Anim. Health Prod, 38, 521-526.

Ali, Y.H.; Khalafalla, A.I.; Gaffar, M.E.; Peenze, I. and Steele, A.D. (2004): Detection and isolation of group A rota virus from camel calves in Sudan. Paper in: The 11th International Conference of the Association of Institutions for Tropical Veterinary Medicine and 16th Veterinary Association Malaysia Congress, 23-27 August 2004, Petaling Jaya, Malaysia, pp 302-304.

Bancroft, J.D. and Stevens, A. (1990): Theory and Practice of Histopathological Techniques. Third edition, New York.

Berrada, J.; Bengoumi, M. and Hidane, K. (1999): Diarrhees neonatales $\mathrm{du}$ chamelon dans les governorate sahariennes du sud du Maroc. Etude bacteriologique. In: Proceedings of International Workshop on the Young Camel, Oct 24th-26th, Vol. 53.

Bridger, J.C. (1987): Novel rota viruses in animals and man, p. 5-15. In G. Brock and J. Whelan (ed.), Novel diarrhoea viruses. Ciba Foundation, John Wiley \& Sons Ltd., Chichester, United Kingdom.

Burleson, F.G.; Chamber, T.M. and Wiedbrank, D.L. (1997): Virlogy:A laboratory Manual.Academic Press, INC,Harcourt Brace Jovanovich, publisher. 
Carpio, M.; Bellamy, J.E.C. and Babiuk, L.A. (1981): Comparative virulence of different bovine rota virus isolates. Can. J. Comp. Med. 45: 38-42.

Cebra, C.K.; Mattson, D.E.; Baker, R.J.; Sonn, R.J. and Dearing, P.L. (2003): Potential pathogens in feces from unweaned llamas and alpacas with diarrhea. J. Am. Vet. Medical Ass. 223: 1806.

Clark, M.A. (1993): Bovine corona virus. Br. Vet. J. 149:51-70.

Claude, F.M.; Mayo, M.A.; Maniloff, J.; Desselberger, U. and Ball, L.A. (2005): "Coronaviridae." Virus Taxonomy: VIIIth Report of the International Committee on Taxonomy of Viruses. $2^{\text {nd }}$ ed.Oxford: Elsevier Academic Press, 947-964.

Decaro, N.; Mari, V.; Desario, C.; Campolo, M.; Martella, V.; Greco, G.; Cirone, F.; Olaianni, M.L.; Cordioli, P. and Buonavoglia, C. (2008): Severe outbreak of bovine corona virus infection in dairy cattle during the warmer season. Vet. Microbiol. 26: 30-39.

Desselberger, U.; Gray, J. and Estes, M.K. (2005): Rota viruses. In: B.W.J. Mahy and V.T. Meulen (eds), Topley and Wilson's Microbiology and Microbial infections, ASM press, USA, 946-958.

Davis, E.; Rush, B.R.; Cox, J.; DeBey, B. and Kapil, S. (2000): Neonatal enterocolitis associated with corona virus infection in a foal:A case report. J. Vet. Diagn. Investig. 12: 153-156.

Dea, S. and Tijssen, P. (1988): Viral Agents Associated with Outbreaks of Diarrhea in Turkey Flocks in Quebec. Can. J. Vet. Res. 52: 53-57.

Dea, S.; Begin, M.E.; Archambault, D.M.A.; Elazhary, S.Y. and Roy, R.S. (1985): Distinct rota viruses isolated from asymptomatic calves. Cornell Vet. 75: 307-318.

Derbyshire, J.B. and Woode, G.N. (1978): Classification of rota viruses: Report from the World Health Organization/Food and Agriculture Organization Comparative Virology Program. J. Am. Vet. Med. Assoc. 173: 519-521.

Elizabeth, D.; Bonnie R. Rush; Cox, J.; DeBey, B. and Kapil, S. (2000): Neonatal enterocolitis associated with corona virus infection in a foal: A case report J. Vet Diagn. Invest. 12: 153-156.

Evermann, J.F. and Benfield, D.A. (2001): Coronaviral Infections. In Infectious Diseases of Wild Mammals, ed. Williams ES and Barker IK, Iowa State University Press, Ames, Iowa. 245-253. 
Fernandes, A. Barry; Alfieri, A.F.; Stipp, D.T. and Alfieri, A.A. (2009): Bovine Corona virus Detection in a Collection of Diarrheic Stool Samples Positive for Group A Bovine Rota virus. Braz. Arch. Biol. Technol. 52: pp. 45-49.

Fukai, K.; Saito, T.; Fukuda, O.; Hagiwara, A.; Inoue, K. and Sato, M. (2006): Molecular characterization of equine group A rota virus, Nasuno, isolated in Tochigi Prefecture, Jpn. Vet. J., 172, 369-373.

Graham, D.Y. and Mary K. Estes (1980): Proteolytic enhancement of rota virus infectivity: Biologic mechanisms. Virology. 101: 432-439.

Ijaz, M.K.; Dent, D.; Haines, D. and Babiuk, L.A. (1989): Development of a murine model to study the pathogenesis of rota virus infection. Experimen. and Molec. Pathol. 51 (2): 186-204.

Jos, B.; Johan, A.H.J.; Reimerink, Anita M.; Korteland-van Male Vanessa J.J.; Van Ham, Marion P.G.; Koopmans, H.A.; Bu“ller, J. Dekker and Alexandra, W.C. Einerhan (2003): Changes in small intestinal homeostasis, Morphology, and Gene Expression during Rota virus Infection of Infant Mice. J. Virol., 77, 24: 13005-13016.

Inaba, Y.; Sato, K.; Takahashi, E.; Kurogi, H.; Satoda, K.; Omori, T. and Matumoto, M. (1977): Hemagglutination with Nebraska calf diarrhea virus. Microbiology and Immunology 21, 531-534.

Kalica, A.R.; Wyatt, R.C. and Kapikian, A.Z. (1978): Detection of differences among human and animal rota viruses, using analysis of viral RNA. J. Am. Vet. Med. Assoc. 173: 531-537.

Lai, M.M.; Perlman, L.S. and Anderson, J. (2006): "Coronaviridae." Fields Virology. $5^{\text {th }}$ ed. David M. Knipe, Peter M. Howley, Diane E. Griffin, Robert A. Lamb, and Malcolm A. Martin. Boston: Lippincott Williams \& Wilkins, 1305-1327.

Linda, J. Saif; Robert, A.H.; Kathy, L.M. and Mohamed, M.T. (1988): Cell Culture Propagation of Bovine Coronavirus. J. Tissue Culture Methods. 11: 3.

Majhdi, F.; Minocha, H.C. and Kapil, S. (1997): Isolation and characterization of a corona virus from elk calves with diarrhea. J. Clin. Microbiol 35: 2937-2942. 
Mayameei, A.; Mohammadi, G.; Yavari, S.; Afshari, E. and Omidi, A. (2009): Evaluation of relationship between Rota virus and Corona virus infections with calf diarrhea by capture ELISA. Comp. Clin. pathol. http://www.springerlink.com.

Mebus, C.A.; Underdahl, N.R.; Rhodes, M.B. and Twiehaus, M.J. (1969): Calf diarrhea (scours) reproduced with a virus from a field outbreak. Univ. Nebr. Res. Bull. 233: 2-15.

Mebus, C.A.; Underdahl, N.R.; Rhodes, M.B and Twiehaus, M.J. (1971): Pathology of neonatal calf diarrhea induced by reo-like virus. Vet. Pathol. 8: 490-505.

Mebus, C.A.; Stair, E.L.; Rhodes, M.B. and Twiehaus, M.J. (1973): Pathology of neonatal calf diarrhea induced by corona virus like agent. Vet. Pathol., 10: 45-64.

Mebus, C.A.; Newmann, L.E. and Stair, E.L. (1975): Scanning electron, light and immunofluorescent microscopy of intestines of gnotobiotic calf infected with calf diarrheal corona virus. Am. J. Vet. Res., 36: 1719-1726.

McNulty, M.S.; Allan, G.M. and Mcfeliran, J.B. (1977): Cell Culture Studies With a Cytopathic Bovine Rotavirus. Arch. Virol. 54, 201-209.

Oliveira Filho, J.P.; Silva, D.P.G.; Pacheco, M.D.; Mascarini, L.M.; Ribeiro, M.G.; Alfieri, A.A.; Alfieri, A.F.; Stipp, D.T.; Barros, B.J.P. and Borges, A.S. (2007): Diarrhea in Nelore calves: Clinical and etiologic study. Braz. J. Vet. Res., 27, 419-424.

Orr, J.P. (1984): Necrotizing enteritis in a calf infected with adenovirus. Can. Vet. J. 25: 72-74.

Park, Su-Jin, C.; Jeong, Soon-Seek Yoon, Hyoun E.; Choy, Linda J.; Saif, Sung-Hee Park; You-Jung Kim; Jae-Ho Jeong; Sang-Ik Park; Ha-Hyun Kim; Bong-Joo Lee; Ho-Seong Cho; Sang-Ki Kim; Mun-I Kang, and Kyoung-Oh Cho (2006): Detection and Characterization of Bovine Corona viruses in fecal specimens of adult cattle with diarrhea during the warmer seasons. J. Clin. Microbio. 44, 9, 3178-3188.

Ramig, R.F. (2004): Pathogenesis of intestinal and systemic rota virus infection. J. Virol., 78, 19: 10213-10220.

Reed, L.J. and Muench, S. (1938): A simple method of estimating fifty percent end point. Am. j. Hyg. 27: 493-497.

Saif, L.I.; Redman, D.R.; Brock, K.V.; Kohler, E.M. and Heckert, R.A. (1988): Winter dysentery in adult dairy cattle: Detection of coronavirus in the faeces. Vet. Rec. 123: 300-301. 
Sato, M.; Nakagomi, T.; Tajima, K.; Ezura, K.; Akashi, H. and Nakagomi, O. (1997): Isolation of Serotype G8, P6 [1] Bovine Rota virus from Adult Cattle with Diarrhea. J. Clinic. Micro. 35, 5, 1266-1268.

Sharpee, R.L.; Mebus, C.A. and Bass, E.P. (1976): Characterization of a calf diarrhoea corona virus. Am. J. Vet. Res., 37: 1031-1041.

Spence, L.; Fauvel, I.; Petro, R. and Bloch, S. (1976): Haemagglutinin from rota virus. Lancet 2: 1023.

Spence, L.; Fauvel, M. and Petro, R. (1978): Comparison of rota virus strains by haemagglutination inhibition. Canad. J. Microbiol. 24, 353-356.

Takiuchi, E.; Stipp, D.T.; Alfieri, A.F. and Alfieri, A.A. (2006): Improved detection of bovine corona virus $\mathrm{N}$ gene in faeces of calves infected naturally by a semi-nested PCR assay and an internal control. J. Virol. Methods, 131, 148-154.

Tibary, A.C.; Fitea, A.; Anouassi, B.C. and Sghirib, A. (2006): Infectious causes of reproductive loss in camelids. Theriogenol. 66: 633-647.

Tzipori, S. (1981): The aetiology and diagnosis of calf diarrhea. Vet. Rec., 108: 510-514.

Tsunemitsu, H.; El-Kanawati, Z.R.; Smith, D.R.; Reed, H.H. and Saif, L.J. (1995): Isolation of corona viruses antigenetically indistinguishable from bovine corona virus from wild ruminants with diarrhea. J. Clin Microbiol 33: 3264-3269.

Vogel, J. and Shelokov, A. (1957): Adsorption-haemagglutination test for influenza virus in monkey kidney tissue culture. Science, 126: 328-329.

Vries, A.A.F.; Horzinek, M.C.; Rottier, P.J.M.D.E. and Groo, R.J.T (1997): The genome organization of the Nidovirales: Similarities and differences between Arteri- Toro-, and Corona viruses. Semin. Virol. 8, 33-47.

Wani, S.A.; Bhat, M.A.; Nawchoo, R.; Munshi, Z.H. and Bach, A.S. (2004): Evidence of rota virus associated with neonatal lamb diarrhoea in India. Trop. Animal Health and Prod., 36, 27-32

Wernery, U. (1999): New aspects of infectious diseases of camelids. J. Camel Pract. Res. 6: 87-91.

Wernery, U. and Kaaden, O.R. (2002): Bacterial diseases and viral diseases. In: Infectious diseases in camelids, ed. Wernery U, $2^{\text {nd }}$ ed., pp. 19-236. Blackwell Science, Berlin, Germany. 
World Health Organization (WHO) (1980): Rota virus and other viral diarrhoeas. 58 (2): 183-198.

Wünschmann, A.; Frank, R.; Pomeroy, K. and Kapil, S. (2002): Enteric corona virus infection in a juvenile dromedary (Camelus dromedaries). J. Vet. Diagn. Investig. 14: 441-444.

Yolken, R.H.; Kim, H.W.; Clem, T.; Wyatt, R.G.; Kalica, A.R.; Chanock, R.M. and Kapikian, A.Z. (1977): Enzyme-linked immunosorbent assay (ELISA) for detection of human reovirus-like agent of infantile gastroenteritis. Lancet, 2: 263-266. 
Assiut Vet. Med. J. Vol. 56 No. 125 April 2010 